\title{
BLOOD GAS AND METABOLIC STUDIES IN PLASMA CELL PNEUMONIA AND IN NEWBORN PREMATURES WITH RESPIRATORY DISTRESS
}

\author{
BY \\ E. KERPEL-FRONIUS, F. VARGA, and G. BATA \\ From the Department of Paediatrics, University of Pécs, Hungary
}

(RECEIVED FOR PUBLICATION MAY 6, 1964)

Hypoxia, acidosis, hyperkalaemia, and hypoglycaemia are believed to be among the ultimate causes of death in infants suffering from respiratory failure. The purpose of this study was to follow these factors from the onset of symptoms to the time of death, and thus to define the preterminal pattern of the metabolic changes.

Respiratory insufficiency of the newborn is a complex clinical picture, and its mechanism is far from clear. Thus it appeared to be advantageous to compare the sequence of events in the hypoxia of newborn premature babies with respiratory distress, with that oocurring in another and simpler condition, plasma cell pneumonia, a disease of somewhat older and usually malnourished prematures. Both these conditions are characterized by severe hypoxia and a high mortality rate. By comparing them, similarities and differences can be emphasized, and a better understanding of events preceding death in both conditions may be achieved.

\section{Material and Methods}

Of the 42 premature babies dying as a result of respiratory distress, $43^{\circ}$ o had birth weights below $1,500 \mathrm{~g}$., $34^{\circ}{ }_{\mathrm{o}}$ between 1,500 and $2,000 \mathrm{~g}$., and $23^{\circ}$ o between 2,000 and $2,500 \mathrm{~g}$. Necropsies revealed massive atelectasis with or without hyaline membranes, accompanied by cerebral haemorrhage in some cases. For the purpose of this study no attempt has been made to separate the cases of hyaline membrane disease from other forms of respiratory insufficiency. Approximately the same weight distribution holds true for the 74 newborn premature infants serving as controls, who were admitted to the clinic either because of feeding problems or transitory respiratory difficulties. The 17 infants with plasma cell pneumonia were 2 to 4 months of age, they were nearly all malnourished premature infants, and at necropsy extensive interstitial plasma cell pneumonia was found.

Arterial samples were obtained from a temporal or femoral artery, and venous samples from the longitudinal sinus cerebral venous blood during the few minutes while the infants were breathing air. Blood was taken under oil, and all samples showing visible traces of haemolysis were discarded. Analyses were made within one hour of securing the blood samples. $\mathrm{O}_{2}$-content was measured according to Van Slyke (1932); blood sugar (true sugar) by the method of Somogyi (1945), plasma potassium by flame photometry, and $p \mathrm{H}$ and $\mathrm{CO}_{2}$-tension according to Astrup (1956). $\mathrm{O}_{2}$-consumption was measured with the Kipp-Noyons diaferometer, and the infants (who were in swaddling clothes at an environmental temperature of 22 C.) had normal rectal temperatures at the time of investigation. Inulin and PAH clearances were studied according to methods described previously (KerpelFronius, Varga, Kun, and Vönöczky, 1954).

\section{Results}

Hypoxia in Plasma Cell Pneumonia. Table 1 shows observations collected on 17 cases of plasma cell pneumonia. The cases are grouped according to severity as judged by arterial $\mathrm{O}_{2}$-saturations measured while breathing air.

It is interesting to note that cerebral arteriovenous $\mathrm{O}_{2}$-difference diminishes with falling arterial saturation. This is probably due, as will be discussed later, to increased blood flow. Venous saturation is also lower than normal; in the absence of a decrease in arteriovenous difference, however, venous saturation would have fallen to even lower levels. These levels could be calculated by subtracting the mean value of arteriovenous $\mathrm{O}_{2}$-difference found in controls $(6 \cdot 6$ vol. $/ 100 \mathrm{ml}$.) from the arterial $\mathrm{O}_{2}$-content measured in individual hypoxic cases. The comparison of these calculated values with those actually observed reveals the importance of increased blood flow in the maintenance of cerebral venous tension, the decrease of which is known to be one of the factors limiting survival in hypoxia.

The effects of $\mathrm{O}_{2}$ administration are described in 


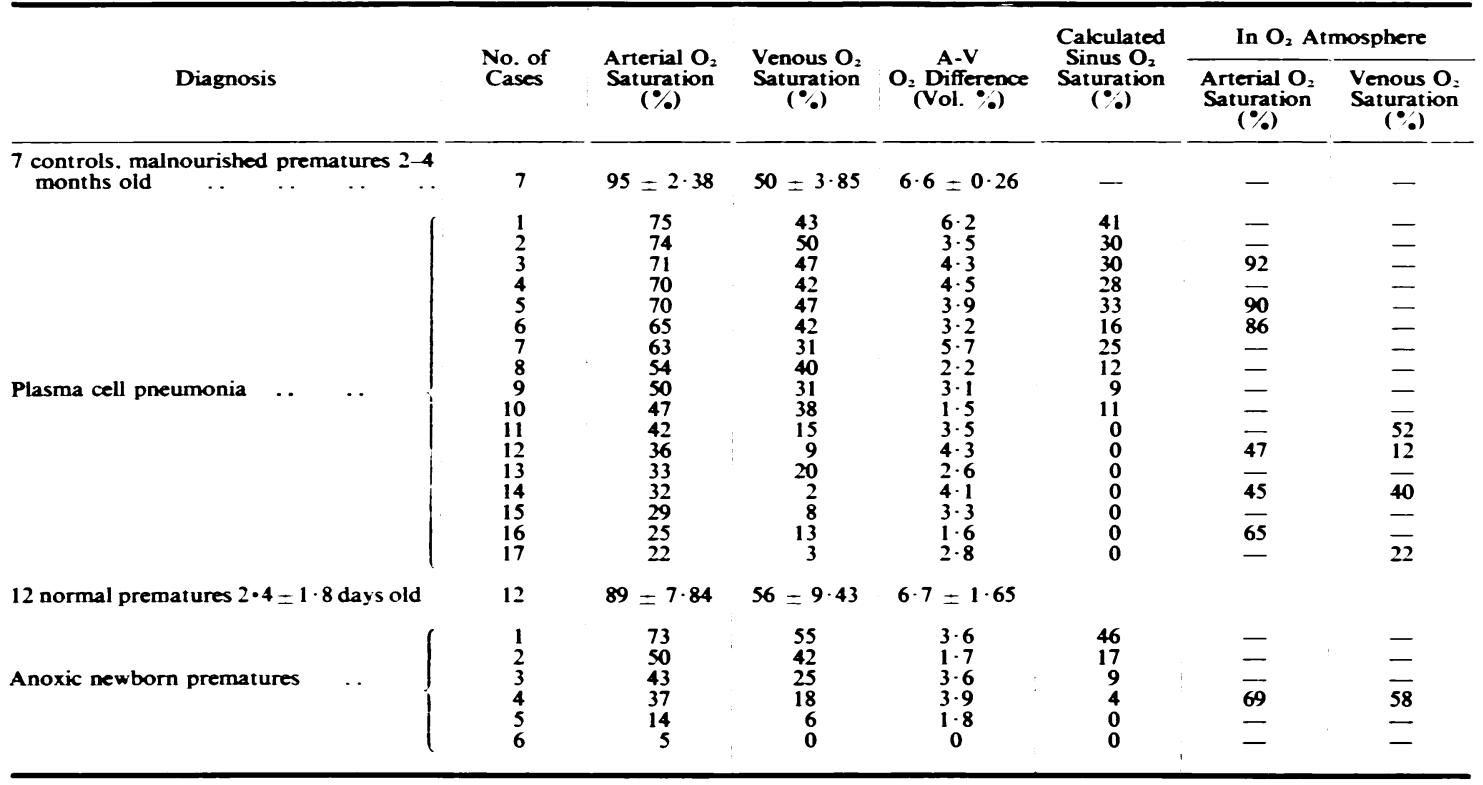

the last column of Table 1. In the 7 cases studied, both arterial and venous $\mathrm{O}_{\mathbf{z}}$-saturations rose

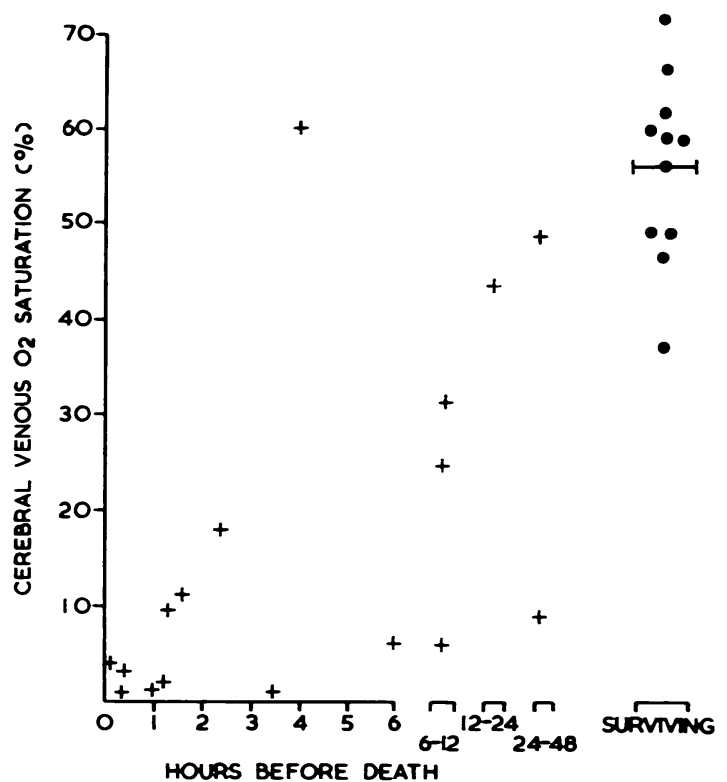

Fig. 1.-Relation of cerebral venous $\mathrm{O}_{2}$ saturation to the time of death in hypoxic newborn prematures. Blood from the longitudinal sinus was taken while the infants were breathing air. Abscissa, time elapsed from sampling blood to the moment of death. considerably when the infants breathed $100^{\circ}{ }_{0}$ oxygen by mask.

Hypoxia in Newborns. The severity of hypoxia in newborn premature infants is comparable with that found in plasma cell pneumonia. Cerebral arteriovenous differences were again found to be small in these cases. Breathing oxygen, arterial saturation improved in the single case studied.

The relation of cerebral venous anoxia to survival time is illustrated in Fig. 1, where cerebral venous saturations are plotted against the time that elapsed from the sampling to death.

Cerebral venous saturations of normal or mildly distressed premature infants varied between $\mathbf{4 0}$ and $70 \%$, the lower figures being rather exceptional. The scatter of these normal values was only a little greater than that of arterial saturations, which varied from $75-98 \%$ in the same infants. In prematures with progressive respiratory distress the cerebral venous $\mathrm{O}_{z}$-saturation, when breathing air, was conspicuously low. As death approached the lowest values were encountered, so that within the last two hours practically no $\mathrm{O}_{2}$ was detectable in venous blood. In some cases, however, very low saturations were observed as early as $\mathbf{6}$ to $\mathbf{2 4}$ hours before death. No doubt the relatively long survival of these infants would have been impossible without $\mathrm{O}_{2}$ administration. 
TABLE 2

Basal O: CONSUMPtion OF PLASMA CELl PNEUMONIA CASES. BREATHING AIR AND $100 \% 0$

\begin{tabular}{|c|c|c|c|c|c|}
\hline \multirow[b]{2}{*}{ Age (mth.) } & \multicolumn{3}{|c|}{ Breathing Air } & \multicolumn{2}{|c|}{ Breathing Oxygen } \\
\hline & $\underset{(\%)}{\text { Arterial } \mathrm{O}_{2}}$ & $\begin{array}{c}\text { Basal } \mathrm{O}_{2} \\
\text { Consumption } \\
\text { (ml. } 1 \cdot 73 \text { sq. } \mathrm{m} .)\end{array}$ & $\begin{array}{c}\text { A-V O } \\
\text { Difference } \\
(\text { Vol. } \%)\end{array}$ & $\begin{array}{c}\text { Arterial } \mathrm{O}_{2} \\
\text { Saturation } \\
(\bullet)\end{array}$ & $\begin{array}{c}\text { Basal } \mathrm{O}_{2} \\
\text { Consumption } \\
(\mathrm{ml} .1 \cdot \mathbf{1} \cdot \mathbf{7 3} \text { sq. } \mathrm{m} .)\end{array}$ \\
\hline $\begin{array}{l}5 \\
6 \\
3 \\
3\end{array}$ & $\begin{array}{l}71 \\
70 \\
65 \\
25\end{array}$ & $\begin{array}{l}157 \\
195 \\
175 \\
178\end{array}$ & $\begin{array}{l}4 \cdot 33 \\
3 \cdot 90 \\
3 \cdot 20 \\
1 \cdot 61\end{array}$ & $\begin{array}{l}92 \\
90 \\
86 \\
65\end{array}$ & $\begin{array}{l}188 \\
210 \\
216 \\
196\end{array}$ \\
\hline $4 \cdot 3=1 \cdot 5$ & $57 \cdot 5=22$ & $176=15$ & $3 \cdot 26=1 \cdot 19$ & $83 \cdot 2=12 \cdot 4$ & $202=13$ \\
\hline
\end{tabular}

TABLE 3

RENAL CLEARANCES IN PLASMA CELL PNEUMONIA

\begin{tabular}{|c|c|c|c|c|c|c|}
\hline & & No. of Cases & $\begin{array}{c}\text { Arterial } \mathrm{O}_{2} \\
\text { Saturation } \\
(\because))\end{array}$ & $\underset{(\%)}{\text { Sinus } \mathbf{O}_{2}}$ & $\begin{array}{c}\text { Inulin } \\
\text { Clearance } \\
\text { (ml. } 1 \cdot 73 \text { sq. m.) }\end{array}$ & $\begin{array}{c}\text { PAH } \\
\text { Clearance } \\
\text { (ml. } 1.73 \text { sq. } \mathrm{m} .)\end{array}$ \\
\hline $\begin{array}{l}\text { Plasma cell pneumonia } \\
\text { Mean .. ‥ .. }\end{array}$ & . & $\begin{array}{l}1 \\
2 \\
3 \\
4 \\
5 \\
6 \\
7 \\
8 \\
-\end{array}$ & $\begin{array}{c}75 \\
75 \\
71 \\
70 \\
63 \\
54 \\
50 \\
47 \\
63=11 \cdot 3\end{array}$ & $\begin{array}{c}43 \\
36 \\
39 \\
42 \\
31 \\
40 \\
31 \\
37 \cdot 5^{38}=4 \cdot 5\end{array}$ & $\begin{array}{c}96 \\
76 \\
101 \\
104 \\
115 \\
56 \\
104 \\
96 \\
92=18 \cdot 8\end{array}$ & $\begin{array}{c}293 \\
347 \\
241 \\
375 \\
392 \\
280 \\
246 \\
259 \\
204=59\end{array}$ \\
\hline $\begin{array}{l}8 \text { controls. mostly maln } \\
\text { prematures }\end{array}$ & rished & 8 & - & - & $62=3 \cdot 88$ & $275=25 \cdot 5$ \\
\hline
\end{tabular}

Basal (minimal) $\mathrm{O}_{2}$ Consumption. As a decrease of basal metabolic rate of about $20^{\circ}$ o was found in newborn babies breathing a gas mixture low in oxygen (Cross, Tizard, and Trythall, 1958), it was of some interest to study the effect of hypoxia on $\mathrm{O}_{2}$ consumption in our clinical cases. Table 2 compares the $\mathrm{O}_{2}$ consumption of infants suffering from plasma cell pneumonia in air and in $100^{\circ} \mathrm{O}_{2}$. Arterial $\mathrm{O}_{2}$-saturation rose from an average of $57.7^{\circ} \mathrm{o}$ in air to $83 \cdot 2^{\circ}$ o in $\mathrm{O}_{2}$, while $\mathrm{O}_{2}$ consumption rose $12 \cdot 8^{\circ}$. According to some preliminary observations on newborn prematures, $\mathrm{O}_{2}$ consumption in them is even more depressed by anoxia.

The effects of hypoxia on general circulation were not studied in detail in the two groups of prematures, but in one case of plasma cell pneumonia, cardiac output (measured directly according to the Fick principle) was found to be double the normal, i.e. $11 \cdot 31 . / 1 \cdot 73$ sq. $\mathrm{m}$.

Renal Clearance. The effects of hypoxia on renal clearances were studied only in the plasma cell pneumonia group of infants (Table 3 ).

High inulin clearance is a conspicuous feature of hypoxia due to plasma cell pneumonia. PAH clearances also appear to be somewhat higher; there are, however, some uncertainties with regard to PAH extraction under the given set of circumstances. Though we did not study clearances in newborn hypoxia, published evidence points to renal disturbance in such cases (McCance and Widdowson, 1954).

Acidosis. Measurements in this study (Table 4) were made on cerebral venous blood; accordingly control and pathological $p \mathrm{H}$ values are somewhat lower than, and $\mathrm{CO}_{2}$-tensions slightly higher than figures for arterial blood.

The cases are arranged according to the severity of acidosis. Simultaneous data on $\mathrm{PCO}_{2}$ and $\mathrm{HCO}_{3}$ show the respective roles of metabolic and respiratory factors in the acidosis. Simultaneously measured $\mathrm{O}_{2}$-saturations indicate the degree of anoxia present.

The data reveal some interesting differences between the two groups of anoxic prematures. First, $p \mathrm{H}$ values are better maintained in plasma cell pneumonia, though the degree of hypoxia judged by cerebral venous $\mathrm{O}_{2}$-saturations is almost the same as in distressed newborns. Secondly, acidosis in plasma cell pneumonia, at this stage of the disease, is predominantly of respiratory origin. Low values of both $\mathrm{HCO}_{3}$ and $\mathrm{PCO}_{2}$ were encountered only in Case 2: in this infant metabolic acidosis was caused by diarrhoea, and it was compensated by blowing off $\mathrm{CO}_{2}$ as shown by the low $\mathrm{PCO}_{2}$. In the remaining cases the high $\mathrm{PCO}_{2}$ accompanied by normal or raised $\mathrm{HCO}_{3}$ indicates that acidosis is due mainly to retention of $\mathrm{CO}_{2}$. 
TABLE 4

ACIDOSIS IN PLASMA CELL PNEUMONIA AND IN NEWBORN ANOXIA

\begin{tabular}{|c|c|c|c|c|c|c|c|c|c|}
\hline Diagnosis & $\begin{array}{l}\text { No. of } \\
\text { Cases }\end{array}$ & $p \mathbf{H}$ & $\underset{(\mathrm{mm} \cdot \mathrm{Hg})}{\mathrm{PCO}_{2}}$ & $\underset{\text { (mEq l.) }}{\text { Plasma }_{3}}$ & $\underset{\left(\begin{array}{c}\circ \\
\text { Sation }\end{array}\right.}{\text { Arterial } \mathrm{O}_{2}}$ & $\underset{\left({ }^{\circ}\right)}{\text { Sinus } O_{2}}$ & $\begin{array}{c}\text { Plasma } \\
\text { K(mEq } 1 .)\end{array}$ & $\begin{array}{l}\text { Blood } \\
\text { Glucose } \\
\text { (mg. } \\
100 \mathrm{ml} \text { ) }\end{array}$ & $\begin{array}{c}\text { Time } \\
\text { Preceding } \\
\text { Death } \\
\text { (hr.) }\end{array}$ \\
\hline $\begin{array}{c}\text { Controls, 3-month-old malnourished } \\
\text { prematures } \ldots\end{array}$ & 6 & $7 \cdot 40=0 \cdot 02$ & $37 \cdot 5=0 \cdot 1$ & $21 \cdot 5=2$ & $95=2 \cdot 38$ & $50=3 \cdot 85$ & $4 \cdot 8=0 \cdot 74$ & $72=10$ & - \\
\hline Plasma cell pneumonia . . . . & $\begin{array}{l}1 \\
2 \\
3 \\
4 \\
5 \\
6 \\
7\end{array}$ & $\begin{array}{l}7 \cdot 40 \\
7 \cdot 33 \\
7 \cdot 29 \\
7 \cdot 27 \\
7 \cdot 23 \\
7 \cdot 16 \\
7 \cdot 10\end{array}$ & $\begin{array}{l}39 \\
27 \\
46 \\
57 \\
80 \\
67 \\
72\end{array}$ & $\begin{array}{l}24 \cdot 2 \\
14 \cdot 5 \\
22 \cdot 3 \\
25 \cdot 8 \\
29 \cdot 6 \\
21 \cdot 0 \\
20 \cdot 2\end{array}$ & $\begin{array}{l}23 \cdot 0 \\
25 \cdot 0 \\
20 \cdot 0 \\
28 \cdot 8 \\
42 \cdot 0 \\
35 \cdot 6 \\
32 \cdot 2\end{array}$ & $\begin{array}{r}5 \cdot 0 \\
6 \cdot 0 \\
3 \cdot 0 \\
0 \cdot 8 \\
15 \cdot 0 \\
8 \cdot 6 \\
2 \cdot 0\end{array}$ & $\begin{array}{l}5 \cdot 3 \\
\overline{4 \cdot 7} \\
5 \cdot 0 \\
\overline{6 \cdot 0} \\
6 \cdot 0\end{array}$ & $\begin{array}{l}82 \\
57 \\
94 \\
\overline{57} \\
60\end{array}$ & $\begin{array}{c}48 \\
12 \\
96 \\
48 \\
12 \\
\text { living } \\
96\end{array}$ \\
\hline Normal prematures $2 \cdot 4=1 \cdot 8$ days old & 12 & $7 \cdot 25=0 \cdot 09$ & $45=2 \cdot 55$ & $17=1 \cdot 68$ & $89=7 \cdot 84$ & $56=9 \cdot 43$ & $6 \cdot 8=1 \cdot 25$ & $41=18$ & - \\
\hline Anoxic newborn prematures .. & $\begin{array}{r}1 \\
2 \\
3 \\
4 \\
5 \\
6 \\
7 \\
8 \\
9 \\
10 \\
11 \\
12 \\
13 \\
14 \\
15 \\
16\end{array}$ & $\begin{array}{l}7 \cdot 25 \\
7 \cdot 17 \\
7 \cdot 13 \\
7 \cdot 12 \\
7 \cdot 03 \\
6 \cdot 98 \\
6 \cdot 97 \\
6 \cdot 86 \\
6 \cdot 86 \\
6 \cdot 82 \\
6 \cdot 79 \\
6 \cdot 76 \\
6 \cdot 65 \\
6 \cdot 64 \\
6 \cdot 46 \\
6 \cdot 45\end{array}$ & $\begin{array}{r}46 \\
78 \\
30 \\
- \\
\overline{77} \\
53 \\
>\quad 100 \\
>100 \\
44 \\
>\quad \overline{100} \\
53 \\
>100\end{array}$ & $\begin{array}{c}18 \cdot 8 \\
26 \cdot 5 \\
10 \cdot 0 \\
- \\
\overline{18 \cdot 4} \\
12 \cdot 5 \\
29.6 \\
17 \cdot 9 \\
14.6 \\
\overline{-} \\
1 \overline{12.6} \\
\overline{3.6} \\
18.5\end{array}$ & $\begin{array}{l}E \\
\bar{Z} \\
\overline{5 \cdot 0} \\
\overline{-} \\
\bar{z} \\
\overline{37 \cdot 0} \\
\overline{-} \\
\overline{-} \\
\overline{-}\end{array}$ & $\begin{array}{c}6 \cdot 0 \\
9 \cdot 0 \\
- \\
- \\
\overline{0} \cdot 0 \\
2 \cdot 0 \\
0 \cdot 0 \\
\overline{18 \cdot 0} \\
\overline{0 \cdot 0} \\
10 \cdot 0 \\
0 \cdot 5 \\
3 \cdot 3 \\
4 \cdot 3\end{array}$ & $\begin{array}{c}5 \cdot 4 \\
3 \cdot 8 \\
5 \cdot 5 \\
- \\
\overline{7 \cdot 2} \\
8 \cdot 0 \\
9 \cdot 6 \\
\overline{5 \cdot 6} \\
\overline{7 \cdot 6} \\
10 \cdot 0 \\
6 \cdot 6 \\
\overline{15}\end{array}$ & $\begin{array}{r}0 \\
15 \\
74 \\
82 \\
73 \\
20 \\
11 \\
0 \\
-150 \\
-90 \\
99 \\
0 \\
140 \\
141\end{array}$ & $\begin{array}{c}8 \\
36 \\
21 \\
18 \\
21 \\
31 \\
3 \frac{1}{3} \\
1 \mathrm{~min} . \\
5 \mathrm{~min} . \\
2 \frac{1}{2} \\
1 \mathrm{~min} . \\
1 \\
1 \frac{1}{3} . \\
20 \mathrm{~min} . \\
1 \mathrm{~min} . \\
10 \mathrm{~min} .\end{array}$ \\
\hline
\end{tabular}

In newborn anoxia the presence of a high $\mathrm{PCO}_{2}$, usually accompanied by a low blood bicarbonate, demonstrates that both metabolic and respiratory factors contribute to the spectacular fall in $p \mathbf{H}$ (James, 1959; Reardon, Baumann, and Haddad, 1960). Case 3 is a rather exceptional one of pure metabolic acidosis: both $\mathrm{HCO}_{3}$ and $p \mathrm{H}$ are low, while low $\mathrm{PCO}_{2}$ indicates partial compensation by blowing off $\mathrm{CO}_{2}$. Preterminally, $\mathrm{PCO}_{2}$ usually rises to extreme levels.

Plasma potassium and glucose levels are presented in Table 4 only to complete the description of the metabolic picture in the individual cases, further data on the subject being presented later.

Analysing the relation between acidosis and survival time, it can be seen that if the $p \mathrm{H}$ is below 7 , life cannot be prolonged more than a few hours. The longest survival time recorded among such infants was only $3 \frac{1}{2}$ hours. No bicarbonate solution was administered in this series.

\section{Błood Glucose.}

Plasma Cell Pneumonia. In premature infants suffering from plasma cell pneumonia hypoxia (Table 5), hypercapnia, or acidosis comparable to that shown in Table 4 was not associated with significant changes in blood glucose levels.

Hypoxic Newborn Premature Infants. In this simple clinical approach to the problem of hypoxia and its metabolic sequelae we endeavoured to collect some information on the preterminal pattern of glucose levels. We were particularly interested, as others have been (Farquhar, 1956; Ward, 1953; Norval, 1950), in whether blood glucose of hypoxic infants more frequently reaches lower levels than that of apparently healthy or surviving prematures of the same age.

In apparently healthy prematures we found (Table 5) as have others (Van Creveld, 1929; Farquhar, 1956; Ward, 1953; Norval, 1950) some strikingly low figures. Values below $20 \mathrm{mg}$. $/ 100 \mathrm{ml}$. (measured by the method of Somogyi-Nelson) were encountered in $10^{\circ}$ o and $18^{\circ} \%$ of all cases on the first and the second day respectively, while figures over $80 \mathrm{mg} . / 100 \mathrm{ml}$. were exceptional in these infants.

In the hypoxic group with unfavourable outcome, the scatter in blood glucose values increases as death approaches, and the great number of both hyper- and hypoglycaemic cases is indeed characteristic of the preterminal pattern. While in apparently healthy prematures more than $80^{\circ}{ }_{o}$ of all values fall in the range between $20-80 \mathrm{mg} . / 100 \mathrm{ml}$., this proportion is reversed in the last two hours of life, more than $80^{\circ} \%$ of all figures being below or above this range. In the last two hours of life in 7 out of 17 cases blood glucose fell below $10 \mathrm{mg} . / 100 \mathrm{ml}$., a value only exceptionally recorded in the control infants. 
TABLE 5

BlOOd GluCOSE IN PLASMa CELl PNEUMONIA, ANOXIC NEWBORN PREMATURES, AND MARASMIC INFANTS

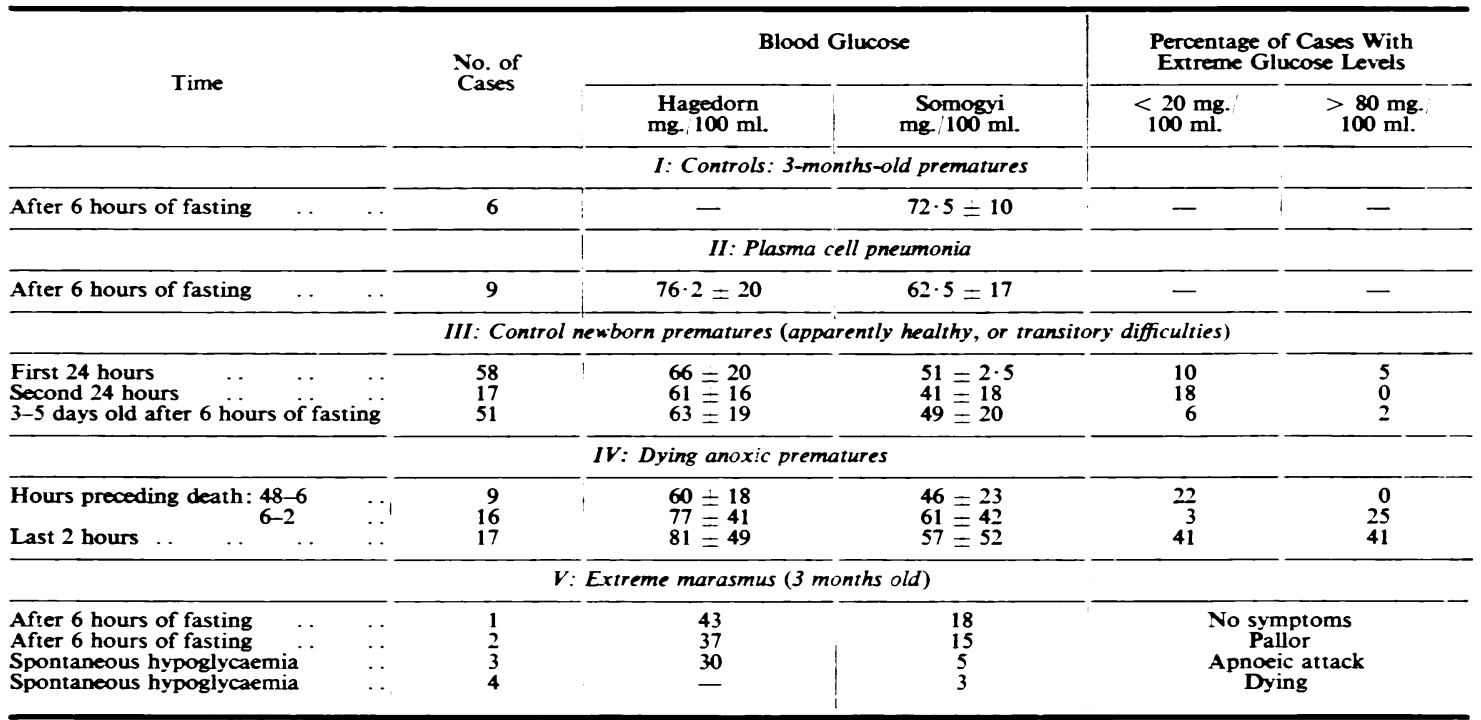

On the other hand high levels of $80-150 \mathrm{mg} . / 100 \mathrm{ml}$. occur in more than $40^{\circ}$ o preterminally, such figures being rare in controls.

To evaluate the clinical significance of hypoglycaemia in hypoxic prematures, some observations on hypoglycaemia in infantile marasmus are also listed in Table 5. Though such infants are similar to newborn prematures with respect to their conspicuous tolerance of hypoglycaemia, this tolerance is not unlimited. With extreme hypoglycaemia, below $10 \mathrm{mg} . / 100 \mathrm{ml}$., sudden collapse sets in, with pallor, gasping respiration, and bradycardia. Glucose injection is followed by striking improvement (Kerpel-Fronius, 1960).

TABLE 6

PLASMA POTASSIUM LEVELS IN PLASMA CELL PNEUMONIA AND IN NEWBORN ANOXIA

\begin{tabular}{|c|c|c|c|c|c|c|}
\hline & & \multirow{2}{*}{$\begin{array}{l}\text { No. of } \\
\text { Cases }\end{array}$} & \multirow{2}{*}{$\underset{(m E q 1 .)}{\text { Plasma K }}$} & \multirow{2}{*}{$\begin{array}{c}\text { OCases } \\
\text { With } \\
\text { K> } 8 \text { mEq } 1 .\end{array}$} & \multicolumn{2}{|c|}{ Red Cells } \\
\hline & & & & & $K(\mathrm{mEq} / \mathrm{l})$ & $\mathrm{Na}(\mathrm{mEq} 1 \mathrm{l})$ \\
\hline $\begin{array}{l}\text { 1: Controls, mostly malr } \\
\text { premature babies, } 2-4 \mathrm{~m}\end{array}$ & $\begin{array}{l}\text { lourished } \\
\text { onths old }\end{array}$ & 8 & $4.8=0.74$ & & & \\
\hline $\begin{array}{l}\text { II: Plasma cell pneumonia, } \\
\text { and nutrition as controls }\end{array}$ & same age & 13 & $5.4 \doteq 0.62$ & & & \\
\hline 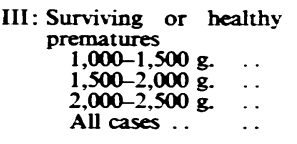 & $\begin{array}{l}\text { newborn } \\
\begin{array}{ll} \\
\ldots & \ldots \\
\cdots & \cdots \\
\cdots & \cdots\end{array}\end{array}$ & $\begin{array}{l}19 \\
39 \\
16 \\
74\end{array}$ & $\begin{array}{l}7 \cdot 30=1 \cdot 08 \\
6 \cdot 90=1 \cdot 17 \\
6 \cdot 00=1 \cdot 23 \\
6 \cdot 80=1 \cdot 25\end{array}$ & $\begin{array}{l}31 \cdot 5 \\
23 \cdot 0 \\
0 \\
20 \cdot 0\end{array}$ & & \\
\hline 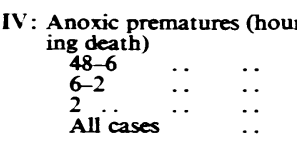 & $\begin{array}{l}\text { s preced- } \\
\begin{array}{ll} \\
\cdots & \cdots \\
\cdots & \cdots \\
\cdots & \cdots\end{array}\end{array}$ & $\begin{array}{l}14 \\
13 \\
12 \\
39\end{array}$ & $\begin{array}{l}6 \cdot 80=2 \cdot 43 \\
6 \cdot 80=1 \cdot 30 \\
10 \cdot 0=4 \cdot 36 \\
7 \cdot 75=2 \cdot 70\end{array}$ & $\begin{array}{l}28 \cdot 5 \\
23 \cdot 1 \\
66 \cdot 6 \\
38 \cdot 4\end{array}$ & & \\
\hline 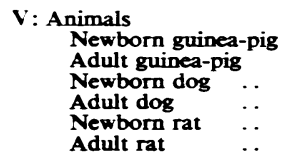 & $\begin{array}{l}. . \\
\cdots \\
\cdots \\
\cdots \\
\cdots\end{array}$ & $\begin{array}{r}32 \\
8 \\
32 \\
6 \\
164 \\
18\end{array}$ & $\begin{array}{l}4 \cdot 31=0 \cdot 18 \\
5.00=0.40 \\
5 \cdot 14=0 \cdot 66 \\
4 \cdot 15=0.10 \\
6.13=0.32 \\
4.31 \pm 0.40\end{array}$ & & $\begin{array}{c}100.4 \pm 4.8 \\
107.5 \pm 3.5 \\
16.0 \pm 3.7 \\
7.25 \pm 1.9 \\
=\end{array}$ & $\begin{array}{rl}16 \cdot 2 & =1 \cdot 8 \\
16 \cdot 3 & =2.8 \\
100 \cdot 0 & 7 \cdot 88 \\
120 \cdot 0 & 5 \cdot 0 \\
& =\end{array}$ \\
\hline
\end{tabular}


Plasma Potassium. In 13 cases of plasma cell pneumonia hypoxia and acidosis were associated with only slightly higher plasma potassium than in control prematures of the same age and nutritional condition. This small rise can probably be accounted for by acidosis, since, according to Burnell, Villamil, Uyeno, and Scribner (1956), there is for every $0 \cdot 1$ unit of change in $p \mathrm{H}$, an average inverse change of $0.6 \mathrm{mEq} / 1$. in the plasma potassium concentration.

Newborn Premature Infants. In our control material consisting of 74 prematures, aged 1-5 days, $78^{\circ}{ }_{o}$ with birth weights below $2,000 \mathrm{~g}$., presenting no, or only transitory, difficulties, we obtained a rather high mean potassium concentration of $6 \cdot 8=1 \cdot 25$ $\mathrm{mEq} / \mathrm{l}$. (Table 6). The highest values were found in the group with the lowest birth weights, while in the weight group of $2,000-2,500 \mathrm{~g}$. the mean value was $6 \cdot 00=1.25 \mathrm{mEq} / 1$.

The question whether higher potassium levels should be considered as a physiological attribute of 'immaturity' may be approached also from the point of view of comparative physiology. Newborn guinea-pigs, considered to be relatively 'mature' at birth, were found to have somewhat lower potassium levels than adult animals, while the more 'immature' newborn rat and dog have a significantly higher potassium level than the corresponding adult animals.

The mean concentration of plasma potassium in our anoxic cases with unfavourable outcome was higher than in the control group only in the last two hours of life. The preterminally higher mean value is due to the large proportion of infants with levels over $8 \mathrm{mEq} / 1$. Such figures occurred in two-thirds of all cases in the last two hours of life, as contrasted with one-fifth of surviving cases.

\section{Discussion}

One aim was to study the extent and the frequency of gaseous and metabolic changes thought to have a bearing on the outcome of hypoxia in hypoxic newborn prematures. The data collected reveal that hypoxia and acidosis follow a rather similar pattern. These alterations increase in severity in all cases as the time of death approaches.

Decrease in $\mathrm{O}_{2}$-saturation of cerebral venous blood of the extent found in our cases may have disastrous effects. A critical value of cerebral venous pressure was considered by Opitz and Schneider (1950) to be the common denominator in bringing about many clinical symptoms of anoxia in both the anoxic and the stagnant types. In acute experimental anoxic anoxia unconsciousness has been observed at cerebral venous $\mathrm{O}_{2}$-tensions of $20-17 \mathrm{~mm} . \mathrm{Hg}$. At lower tensions circulatory inadequacy with dilatation of the heart ensues, in turn provoking cerebral ischaemia and death. In anoxia of the stagnant type, for instance in infants with diarrhoeal dehydration. the mortality rate increases with the severity of cerebral venous anoxia (Kerpel-Fronius, Varga, and Kun, 1950; Kerpel-Fronius et al., 1954).

The other constant change was a progressive reduction in $p \mathrm{H}$, and all the cases exhibiting $p \mathrm{H}$ values below 7 died within a few hours.

One of the striking findings was the great frequency of both hypo- and hyperglycaemia during the last hours of life. Severe hypoglycaemia was shown to be responsible for apnoeic spells, coma, and eventual death in both the newborn and the marasmic infant, in keeping with the possibility that hypoglycaemia may be one of the ultimate causes of death in some hypoxic infants.

The mechanism of the hyperglycaemia observed in $41^{\circ}$ o of our dying infants is obscure.

In dealing with hyperkalaemia, stressed by Usher (1959) in newborn anoxia, we first have to discuss uncertainties concerning 'normal' potassium levels in prematures. A number of authors (Kotikoff, 1933; Widdowson and McCance, 1956; Pincus, Gittleman, Saito, and Sobel, 1956; Usher, 1959) reported higher concentrations in premature infants than are normal in adults. In the opinion of Keitel (1959), whose findings in healthy prematures varied within a range of $3 \cdot 8-6 \cdot 2 \mathrm{mEq} / \mathrm{l}$., higher potassium concentrations than these are either pathological or artefact (red cells of the newborn baby readily give up their potassium in vitro).

In our control group the mean potassium concentration was higher than the accepted normal in adults. These results are in agreement with those reported recently by Nicolopoulos and Smith (1961) in a similar group of prematures. Plasma potassium concentration also was found to be higher in newborn dogs and rats than in corresponding adult animals. The dog is a particularly suitable species to study, since its red cells contain mainly sodium and only small amounts of potassium. High plasma potassium in this animal does not, therefore, seem to be an artefact due to the in vitro release of intracellular potassium. The data discussed here suggest, with the reservations stressed by Keitel, that somewhat higher plasma potassium concentrations than those found in normal adults may be considered as a physiological feature of immaturity. A large proportion of hypoxic infants exhibited preterminally higher plasma potassium levels than our control infants. It should be recalled in this connexion that preterminal hyperkalaemia is also frequently seen in 
children dying from diverse causes (Walia, Chandra, Sarin, and Ghai, 1963).

The data discussed again stress the necessity for vigorous $\mathrm{O}_{2}$ therapy and, as shown clinically (Usher, 1959) and also experimentally in acute anoxia (Dawes, Mott, Shelley, and Stafford, 1963), the importance of maintaining carbohydrate stores and $p \mathrm{H}$.

The second aim has been to compare the metabolic changes found in hypoxia of newborn prematures, with those in older prematures suffering from plasma cell pneumonia. When infants exhibiting a similar degree of hypoxia in cerebral venous blood are compared, some differences are noted between the two groups of infants (Table 4). Both potassium and glucose levels show only moderate changes in plasma cell pneumonia but marked changes in many newborns. There is a striking difference in $p \mathrm{H}$, acidosis being extremely severe in newborns and less so in plasma cell pneumonia. If the newborns that preterminally exhibited $\mathrm{CO}_{2}$-tensions above $100 \mathrm{~mm}$. $\mathrm{Hg}$ are excluded, retention of $\mathrm{CO}_{2}$ is comparable in the two groups, so that the difference is due to the metabolic acidosis in the newborns. In spite of much the same degree of hypoxia in cerebral venous blood, the plasma cell pneumonia cases lived longer than the hypoxic newborns (Table 4).

The explanation for the differences found in the two clinical groups might be very simple: oxygen therapy might have been more effective in plasma cell pneumonia than in newborn anoxia. Since oxygen had been administered continuously to both groups of infants, greater effectiveness of this treatment in the plasma cell cases would mean that in spite of hypoxia of about the same severity when breathing air, they had been less hypoxic when breathing oxygen. More limited effectiveness of oxygen therapy would also account for the severer metabolic changes shortening survival in the newborn.

On the other hand better circulatory and renal adjustments in the older prematures may also contribute to the differences observed. In adults circulatory adjustments are known to occur in response to hypoxia. Cerebral blood flow increases as a result of higher cardiac output (Asmussen and Chiodi, 1941 ; Kety and Schmidt, 1948) and decreasing vascular resistance (Kety and Schmidt, 1948). The fall in cerebral arteriovenous $\mathrm{O}_{2}$-difference found in our infants suffering from pneumonia probably also reflects increased cerebral blood flow. It is realized that the arteriovenous $\mathrm{O}_{2}$-difference, being a function of both blood flow and oxygen consumption of the brain, is in itself a measure of neither. For instance, interference with $\mathrm{O}_{2}$-uptake of the brain owing to hypoglycaemia or severe acidosis, as well as decrease in general metabolism, could also account for a fall in arteriovenous $\mathrm{O}_{2}$ difference. But while such factors were shown to be present in cases of neonatal hypoxia, neither $p \mathrm{H}$ nor blood glucose was found to be very low, and general metabolism was only moderately decreased in hypoxia of the older prematures. In one of these infants studied cardiac output was high, and high inulin clearances also suggest unimpaired circulation. Well-maintained renal function may also have played a role in a better defence against acidosis in this group of infants.

In contrast to the plasma cell pneumonia cases. available information suggests impairment of circulation (Neligan, 1959; Burnard, 1959; Rudolph, Drorbaugh, Auld, Rudolph, Nadas, Smith, and Hubbell, 1961) and of renal function (McCance and Widdowson, 1954; James, 1959) at the degree of hypoxia observed in our newborns. The kidneys of the newborn are also less capable of excreting hydrogen ions (Hatemi and McCance, 1961).

Further studies comparing the effectiveness of $\mathrm{O}_{z}$ administration and of tissue and renal defence against acidosis may bring an answer to the causes of the differences noted between the two groups of hypoxic prematures.

\section{Summary}

Blood gases and certain metabolic functions were compared in a series of 2-4-month-old premature infants with plasma cell pneumonia, and in newborn prematures with hypoxia due to respiratory insufficiency.

In plasma cell pneumonia low arterial $\mathrm{O}_{2}$-saturation is accompanied by a large decrease in cerebral arteriovenous $\mathrm{O}_{2}$-difference, resulting in relatively well-maintained venous cerebral $\mathrm{O}_{2}$-saturation. Evidence points to increased circulation in such cases, while basal $\mathrm{O}_{2}$ consumption is somewhat decreased. Inulin clearances are high. Blood $p \mathrm{H}$ is moderately decreased, acidosis being predominantly of respiratory origin. Hyperkalaemia is only moderate and blood glucose is normal.

In hypoxic newborn prematures cerebral arteriovenous $\mathrm{O}_{2}$-difference is small. Acidosis in this group is, at a comparable degree of hypoxia and hypercapnia, more severe than in plasma cell pneumonia, and the acidosis is of both respiratory and metabolic type. Preterminally the blood glucose level is either abnormally low or abnormally high. Hyperkalaemia is mainly seen in the preterminal phase.

With a comparable degree of cerebral hypoxia and hypercapnia (measured when breathing air) the 
infants suffering from plasma cell pneumonia survived longer than the newborns.

\section{References}

Asmussen, E., and Chiodi, H. (1941). The efiect of hyporemia on ventilation and circulation in man. Amer. J. Physiol., 132, 426.

Astrup, P. (1956). A simple electrometric technique for the determination of carbon dioxide tension in blood and plasma. Scand. J. clin. Lab. Invest.. 8, 33.

Burnard, E. D. (1959). Changes in heart size in the dysponcic newborn baby. Brit. med. J., 1, 1495.

Burnell, J. M., Villamil, M. F., Uyeno, B. T., and Scribner, B. H. (1956). The effect in humans of extracellular pH change on the relationship between serum potassium concentration and intracellular potassium. J. clin. Invest., 35, 935.

Cross, K. W., Tizard, J. P. M., and Trythall, D. A. H. (1958). The gaseous metabolism of the new-born infant breathing $15 \%$ oxysen. Acta paediat. (Uppsala), 47, 217.

Dawes, G. S., Mott, J. C., Shelley, H. J., and Stafiord, A. (1963). The prolongation of survival time in asphyxiated immature foetal lambs. J. Physiol. (Lond.), 163, 43.

Farquhar, J. W. (1956). The significance of hypoglycaemia in the newborn infant of the diabetic woman. Arch. Dis. Childh., 31, 203.

Hatemi, N., and McCance, R. A. (1961). Renal aspects of acid-base control in the newly born. III. Response to acidifying drues. Acta paediat. (Uppala), 50, 603.

James, L. S. (1959). Physiology of respiration in newborn infants and in the respiratory distress syndrome. Pediatrics, 24, 1069.

Keitel, H. G. (1959). The concentration of potassium in the plasma. A.M.A. J. Dis. Child., $97,583$.

Kerpel-Fronius, E. (1960). Volume and composition of the body fluid compartments in severe infantile malnutrition. J. Pediat., 56, 826.

_- Varga, F., and Kun, K. (1950). Cerebral anoxia in infantile dehydration. Arch. Dis. Childh., 25, 156. ,,,-- , and Vönöczky, J. (1954). The relationship between circulation and kidney function in infantile dehydration and malnutrition. Acta med. Acad. Sci. hang., 5, 27.

Kety, S. S., and Schmidt, C. F. (1948). The effects of altered arterial tensions of carbon dioxide and oxyen on cerebral blood fow and cerebral oxyzen consumption of normal young men. J. clin. Invest., 27, 484.

Kotikoff, J. A. (1933). Ober den Mineralgehalt im Blute der Kinder im ersten Lebensjahr. Jb. Kinderheilk., 138, 280.
McCance, R. A., and Widdowson, E. M. (1954). The influence of events during the last few days in utero on tissue destruction and renal function in the first two days of independent life. Arch. Dis. Childh., 24, 495.

Neligan. G. A. (1959). The systolic blood pressure in neonatal asphyxia and the respiratory distress syndrome. A.M.A.J. Dis. Child., S3, 460.

Nicolopoulos, D. A., and Smith, C. A. (1961). Metabolic aspects of idiopathic respiratory distress (hyaline membrane syndrome) in newborn infants. Pediatrics, 23, 206.

Norval, M. A. (1950). Blood sugar values in premature infants. J. Pediat., 36, 177.

Opitz, E., and Schneider, M. (1950). Ober die Saverstoffversorgung des Gehirns und den Mechanismus von Mangelwirkungen. Engebr. Physiol., 46, 126.

Pincus, J. B., Gittleman, I. F., Saito, M., and Sobel, A. E. (1956). A study of plasma values of sodium, potassium, chloride, carbon dioxide, carbon dioxide tension, suge, urea and the protein basebindines power, pH and hematocrit in prematures on the first day of life. Pediatrics, 18, 39.

Reardon, H. S., Baumann, M. L., and Haddad, E. J. (1960). Chemical stimuli of respiration in the early neonatal period. J. Pediat., 57 , 151.

Rudolph, A M. Drorbaugh J. E, Auld, P. A. M., Rudolph, A. J., Nadas, A. S., Smith, C. A., and Hubbell, J. P. (1961). Studies on the circulation in the neonatal period. Pediatrics, 27, 551

Somogyi, M. (1945). A new reagent for the determination of sugar. J. biol. Chem., 10, 61.

Usher, R. (1959). The respiratory distress syndrome of prematurity I. Changes in potassium in the serum and the electrocardiogram and effects of therapy. Pediatrics, $24,562$.

Van Creveld, S. (1929). Carbohydrate metabolism of premature infants. I. The blood sugar during fasting. Amer. J. Dis. Child., 38, 912.

Van Slyke, D. D. (1932). In Owantitative Clinical Chemistry, ed. J. P. Peters and D. D. Van Styke. Vol. II. Methods. William and Wilkins, Baltimore.

Walia, B. N. S., Chandra, R. K., Sarin, G. S., and Ghai, O. P. (1963) Preterminal and postmortem changes in serum-potassium of children. Lancet, 1, 1187.

Ward, O. C. (1953). Blood sugar studies on premature babies. Arch. Dis. Childh., 28, 194.

Widdowson, E. M., and MoCance, R. A. (1956). The effect of development on the composition of the serum and extracellular fhuids. Clin. Sci., 15, 361. 